\title{
On English Teaching in Maritime Colleges
}

\author{
Jiang Shen \\ Navigation College, Dalian Maritime University, Dalian 116026, Liaoning, China \\ Tel: 86-411-84729640 E-mail: shenjiang@dl.cn \\ Honggui Wang \\ Navigation College, Dalian Maritime University, Dalian 116026, Liaoning, China \\ Tel: 86-411-84729640Ｅ-mail: mike_whg@126.com
}

Received: September 8, $2010 \quad$ Accepted: September 22, 2010 doi:10.5539/elt.v4n2p176

\begin{abstract}
According to English level of Chinese ocean sailors at present, we analyze the characteristics and instruction needs of navigation English and point out current English teaching in maritime specialty has many problems. Traditional teaching modes are not suitable for modern maritime needs any longer. So we propose feasible methods and countermeasures on how to improve English teaching in maritime specialty of Chinese colleges. Hopefully advanced sailors with high quality and adapting modern navigation will be brought up.
\end{abstract}

Keywords: Maritime English, English Level, English Teaching, Maritime Student

\section{Research Questions}

China has great maritime power, with over 4000 ocean ships traveling all over the world. An amount of ocean sailors needs to be supplied every year. China exports a great deal of maritime service, and ten thousands of sailors provide with maritime service to their ship-owners from many countries, so plenty of ocean sailors are needed for that as well. The graduates from maritime colleges are the main channels of supplementing advanced sailor. Therefore, the instruction effects of maritime colleges directly influence the quality and competency capacity of sailors.

However, currently many ship-owners complain Chinese sailors' poor English, and quite lot sailors are refused just because of low-leveled English. Many sailors, who are interviewed by ship-owners, can just briefly introduce themselves in English. So English level seriously affects Chinese sailors' quality and competency capacity and restricts Chinese exports of labor service currently. Many ship-owners would rather spend much more money in hiring Indian or Philippine sailors with good English level but a little poor ability. For instance, the population of Philippines is only over 80 million, but annual sailor service exports maintain around 250 thousand. However, China has the most population of more than 1.3 billion, including over 500 thousand various sailors. Although Chinese sailor labor is cheap (even cheaper than that of Vietnam), annual labor exports are always around 50 thousand. So it is very significant to improve maritime English teaching effects in order to further Chinese sailors' quality and increase their labor market share.

\section{Current Situation of Chinese Maritime English Teaching}

According to Chinese present education system, the students of maritime colleges should study for at least 15 years (6 years in primary school, 3 years in middle school and senior school respectively and 3 or 4 years in college) in schools. They are taught English for at least 9 years and maritime English for over 3 years. However, after studying English for so many years, many students still can't be competent to ocean work with poor English. Quite a lot graduates from maritime colleges can't understand ordinary voyage orders, charter contracts, ship owners' instructions, and can't make necessary language communication with ship-owners and related parties. Although some sailors are hired, the ship-owners often complain or send them back because of their low-leveled English. We can see maritime English teaching in maritime colleges does not adapt to modern navigation needs any longer. The represented details are as follows.

\subsection{Teaching Content Lagging}

Modern navigation develops so rapidly that many new types of ships are put into using every year all over the world, and many new laws and regulations are established. However, the English textbooks chosen by most of Chinese maritime colleges are "famous, experienced and popular classic works", whose contents have nothing to do with ocean transportation. Although some contents have certain relationship with navigation, they are out of date. For 
instance, SOLAS/MARPOL/STCW, the important conventions in navigation field, seldom or never shows up in maritime English textbooks. The regulations like ISM/ISPS are the bases of governments, port authorities and shipping companies to regulate and administrate ships, but it is very hard to find them in maritime English textbooks too.

\subsection{Simple Instruction Methods}

Maritime English is a very practical course. Owing to foreign-involved ocean transportation, the sailors have to face foreigners. So the students should be improved on their English level from three aspects, i.e. "listening, speaking and writing". Maritime English consists of not only reading comprehension, but also oral conversation, writing ability and typing speed. However, for present maritime English teaching, similar examination method with other courses, i.e. paper examination, is being implemented. So many courses are set up firmly embaying how to improve students' reading comprehension, which causes that a student can get good marks as long as he or she remember English words. Thus they ignore the training of oral English, listening comprehension and writing ability to the students, so that many students can't speak and understand English on working, and hold "dummy English". Marine sector seldom contacts foreigners, so the "dummy English" is more obvious. The best evidence is that foreign ship-owners always complain so few Chinese people can communicate in English.

\subsection{Pursue Examination Pass Rate Unilateral}

If maritime students are willing to become manipulation or management sailors, they have to pass examinations first to achieve relevant competency certificates. No matter for what level of examinations, maritime English is a compulsory subject. So many colleges focus on instructing students how to deal with sailor examinations, and regard pass rate as a main target of measuring teaching achievements. At present, there are corresponding test database and publications on every subject of sailor examinations, moreover, many exam questions are just from the test database. So as long as remembering test database, the students can pass the sailor examinations and get relevant competency certificates. Thus although many students pass the examinations by remembering exam questions, their practical English hasn't been improved at all. As far as anything beyond exams is concerned, the students are all at a loss, and make misunderstanding or unnecessary loss often.

\subsection{Lack of Instruction Target}

Any kind of language has its own characteristics and scope. Experiencing a development for many years, maritime English has formed a set of integrated system. Many professional terms and abbreviations are generated only for maritime English. And many English words and abbreviations have particular meanings in maritime English. Therefore, we should implement targeted instruction according to the characteristics of maritime English. However, many maritime colleges choose the methods and teachers for teaching Basic English to teach maritime English, which must be ineffective. Often, the students "know all words, grasp all grammar, but don't know what they mean". For instance, the $48^{\text {th }}$ term of China Maritime Law states, "The carrier shall properly and carefully load, handle, stow, carry, keep, care for and discharge the goods carried". This sentence consists of very usual English words, but it is hard to understand the real meaning of that without considering the characteristics and scope of maritime English. In the above, "keep" and "care for" both mean "look after", but why do two words with similar meaning exist together? In fact, in maritime English, these two words are different essentially. "Keep" means "look after", but it emphasizes goods quantity is guaranteed, such as avoiding thefts or falling apart. Although "care for" also means "look after", it focuses on good quality is guaranteed. According to goods quality, people should make proper airiness and colligation to ensure the quality. It is obvious that as long as targeting the characteristics and scope of maritime English, we can really understand the maritime meanings. At the same time, there are a large amount of professional terms and abbreviations which can not be found in an ordinary dictionary or have different meanings, so targeted instruction has to be applied to promote instruction effects of maritime English.

\subsection{Little Writing Training}

Sailing ships need to keep paper contact with relevant departments onshore every day (such as e-mail). Meanwhile, ships might encounter various circumstances at any moment, so sailors are required to write corresponding English letters in short time and English writing ability should be mastered. However, present maritime English teaching doesn't include English writing courses, so writing training on maritime is quite little. Thus many students don't know how to write English letters after getting on board, or their English writing doesn't meet the requirements of maritime English. For instance, in ordinary English writing, "good morning/afternoon/evening" are often used for greeting, but maritime English is overseas and the morning of the sender is probably the afternoon or evening of receiver, so usually maritime greeting is "good day".

Many students are lack of writing training and vocabulary, so ocean sailors are too much dependent on dictionary. 
They think they can write right English letters as long as holding a dictionary. Many sailors will write what they want to write in Chinese first, then translate the words into English one by one under the help of dictionary, at last accumulate all the words together. They think people can use their own way to understand what they wrote, but actually the English letters written in the above way is very funny and can't be understood, so misunderstanding is unavoidable. For example, when looking up "ship" in a Chinese-English dictionary, we can find "vessel, tanker, ferry, yacht, boat and ship", and can't distinguish them exactly only by the dictionary, however, they are strictly different in maritime English. Vessel usually refers to ships for cargo, tanker is oil tanker, ferry means ferryboat and yacht refers to barge, etc.

\section{Improvement}

\subsection{Promote Level of Maritime English Teachers}

The lecturers of maritime English should have not only solid knowledge of English, but also abundant maritime knowledge. Graduate teachers of English have advantages on Basic English skill instruction, such as listening, speaking, reading and writing, but they are lack of professional maritime knowledge and can't deepen professional English teaching. Graduate teachers of navigation have certain ocean experiences, which are familiar with professional maritime knowledge. They are advantageous to help students to read professional English materials, literatures and introduce relevant specialization English, however, they can't meet the requirements that English teachers should have, such as pronunciation, vocabulary and English teaching methods, so that the students are affected and restricted on improving English level. Different teachers with different background have their own advantages and disadvantages respectively. Firstly, we have to improve lecturers' teaching skill in order to entirely improve students' English level. Teachers need to be arranged on corresponding training and advanced study as planned based on their different knowledge structure.

\subsection{Choose Right Textbooks for Maritime Teaching}

Maritime colleges should choose professional English textbooks related to latest maritime technology so that the students can learn not only maritime English but also latest maritime technology and regulations. For the students of good English level, if possible, they can use relevant English textbooks in order to achieve a multiplier effect.

\subsection{Improve Examination Mode}

Mostly Present maritime colleges implement final paper exams, thus most of students concentrate on dealing with paper exams, but are indifferent with "listening, speaking and writing". We can imagine, if exam mode is improved, that is to say, in final exams of every semester testing students on their English skill with several ways, i.e. listening, speaking and writing, students' enthusiasm to English studying will be greatly stimulated and English skill will be promoted systematically.

\section{4 Increase Oral English Teaching}

Maritime oral English and English reading are equally important. When a ship reaches another country, what is needed firstly is to communicate with the port authority through VHF. Ship-owners always test sailors' competency capacity starting from oral English level. Therefore, we should increase oral English teaching hours on maritime English instruction, create oral practice atmosphere, and simulate certain scene conversation.

\section{Several Suggestions}

\subsection{On Teachers}

STCW78/95 states definite standard on professional English skill of maritime sailors. However, China has no any competency standard on teachers who are engaged in maritime teaching and training so far. Maritime English has neither too much profound grammar nor many dissocial new words, but some daily English besides abundant professional terms and abbreviations. So when choosing maritime English teachers, we should take priority of experienced graduate teachers of navigation on comparatively low English level, and try to avoid choosing high-English-leveled teachers who are lack of maritime knowledge. The author had over ten-year ocean experience before maritime English teaching career, from which I benefit a lot on maritime English teaching.

\subsection{Apply Various Teaching Modes}

The purpose of maritime English teaching is to enable students really grasp maritime English "listening, speaking and writing". In daily teaching, we should apply various teaching modes, such as multimedia teaching, present teaching and board teaching. Teachers can combine maritime practice to explain maritime English in order to stimulate students' interest. Simultaneously, we should invest on modern teaching equipments to entirely improve teaching condition, including video, internet, multimedia teaching platform and navigation simulator. 


\subsection{Create Different Types of Opportunities for Practicing Oral English}

Ocean sailors need to communicate with people from many countries in English. People from different nations hold a little local dialect and tone more or less when speaking English (just like different dialect from different provinces in China). So only through a great deal of practice, they can get improvement on listening and understanding. During daily teaching, we should create various types of opportunities for practicing oral English as much as possible, such as English corner, English salon and English forum, so that students can understand and speak out English. If it is necessary, we can recruit overseas teachers to promote simulation degree so as to entirely improve students' English listening and speaking skill.

\section{4 Open Relevant Minor Courses}

Ocean transportation involves ship agency, freight agency, maintenance management and other relevant fields. Different fields involve different professional requirements, so we suggest good colleges should select experienced teachers and open some maritime minor courses, such as "maritime English communication", "maritime English writing", which must be popular among good students.

\section{Conclusion}

A sailor's English skill determines his competency capacity to great extent. Improving maritime English teaching effects is an important approach of promoting sailors' English level. Therefore, maritime colleges should flexibly and properly apply a variety of scientific and effective teaching methods and means based on their practical teaching respectively, so as to improve present instruction mode, promote English teaching quality, increase Chinese sailor's international labor market share, and construct a strong maritime China as early as possible.

\section{References}

Qi Zhiying. (2004). Business English writing [M]. Beijing: Mechanical Industry Press.

Shen Jiang. (2007). Navigation English Teaching and Its Improvement. Maritime Education Research. (4):32-34.

Wang Jianping. (1998). English Writing on Ocean Sailing Dalian: Dalian Maritime University Press.

Wang Yuange. (2007). Business English Letter Writing. Beijing: Beijing University Press.

Zhao Bingbing. (2002). On Several Issues of Maritime English Training. World Ocean. (2):21-22. 